\title{
Understanding depression in type 2 diabetes: a biological approach in observational studies [version 1; peer review: 2
}

\section{approved]}

\author{
Thomas van Sloten ${ }^{1-3}$, Miranda Schram (iD)1,2,4 \\ ${ }^{1}$ Department of Internal Medicine, Maastricht University Medical Centre, Maastricht, The Netherlands \\ ${ }^{2}$ CARIM School for Cardiovascular Diseases, Maastricht University, Maastricht, The Netherlands \\ ${ }^{3}$ Departments of Epidemiology and Arterial Mechanics, INSERM U970 and Paris-Cardiovascular Research Center, Paris, France \\ ${ }^{4}$ Heart and Vascular Centre, Maastricht University Medical Centre, Maastricht, The Netherlands
}

V1 First published: 14 Aug 2018, 7(F1000 Faculty Rev):1283

https://doi.org/10.12688/f1000research.13898.1

Latest published: 14 Aug 2018, 7(F1000 Faculty Rev):1283

https://doi.org/10.12688/f1000research.13898.1

\section{Abstract}

Depression is twice as common in type 2 diabetes as in the general population and is associated with adverse health outcomes. Growing evidence suggest that type 2 diabetes and depression share biological mechanisms. This brief commentary discusses current understanding of shared biological pathways, focussing on hyperglycaemia, (micro)vascular dysfunction, and low-grade inflammation. Although there is accumulating evidence that these pathways are involved in the link between type 2 diabetes and depression, direct evidence of their temporal associations is lacking because of a paucity of longitudinal studies that focus on the pathobiology of both type 2 diabetes and depression.

\section{Keywords}

type 2 diabetes, depression, hyperglycaemia, (micro-)vascular dysfunction, low-grade inflammation

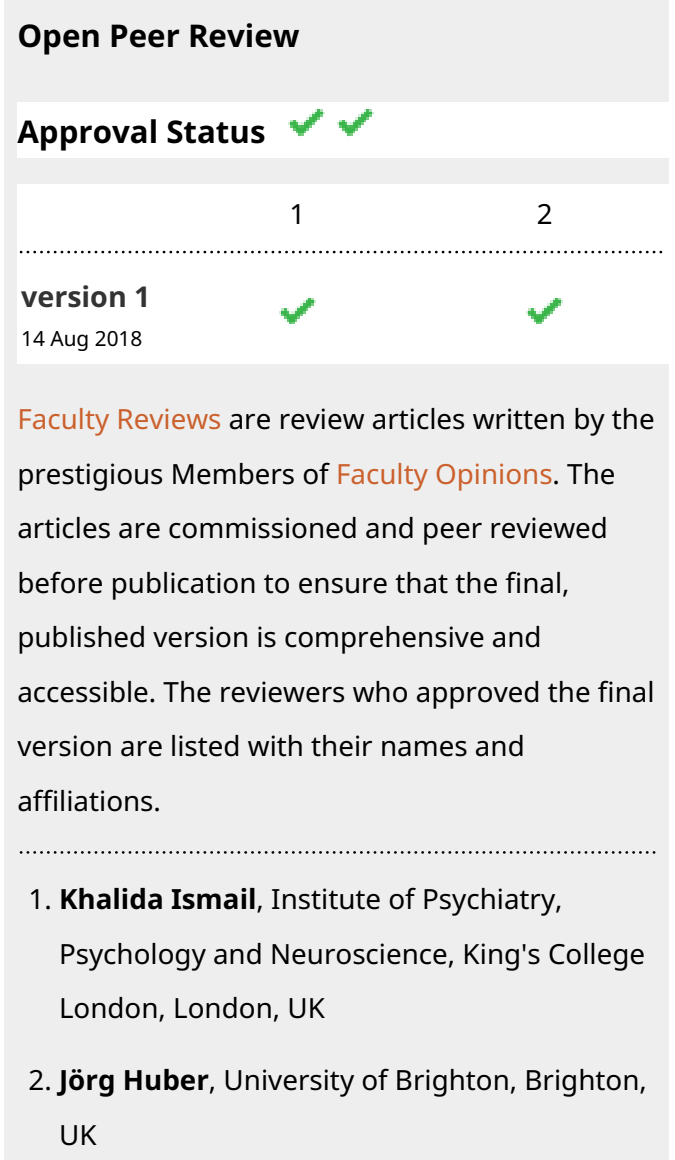

Any comments on the article can be found at the end of the article. 
Corresponding author: Miranda Schram (m.schram@maastrichtuniversity.nl)

Author roles: van Sloten T: Conceptualization, Investigation, Writing - Original Draft Preparation, Writing - Review \& Editing; Schram M : Conceptualization, Investigation, Supervision, Writing - Original Draft Preparation, Writing - Review \& Editing

Competing interests: No competing interests were disclosed.

Grant information: The author(s) declared that no grants were involved in supporting this work.

Copyright: @ 2018 van Sloten T and Schram M. This is an open access article distributed under the terms of the Creative Commons Attribution License, which permits unrestricted use, distribution, and reproduction in any medium, provided the original work is properly cited.

How to cite this article: van Sloten T and Schram M. Understanding depression in type 2 diabetes: a biological approach in observational studies [version 1; peer review: 2 approved] F1000Research 2018, 7(F1000 Faculty Rev):1283

https://doi.org/10.12688/f1000research.13898.1

First published: 14 Aug 2018, 7(F1000 Faculty Rev):1283 https://doi.org/10.12688/f1000research.13898.1 


\section{Introduction}

Type 2 diabetes and depression are common, complex conditions that carry a large disease burden. Moreover, diabetes and depression commonly co-occur; individuals with type 2 diabetes have a doubled risk for depression as compared with individuals without diabetes ${ }^{1,2}$. Furthermore, individuals with depression have a 1.5 higher risk of diabetes ${ }^{3}$. The joint presence of diabetes and depression is burdensome and is frequently overlooked despite the strong, negative impact on the quality of life of those who are affected. In addition, depression in diabetes is associated with higher health-care costs ${ }^{4}$ and loss of productivity and higher absence from work ${ }^{5}$. But this is not the full picture of the negative consequences of depression in diabetes. In longitudinal studies, patients with both diabetes and depression were found to have a considerably higher risk of developing microvascular and macrovascular complications of diabetes, in addition to a 50\% higher mortality risk, as compared with patients without depression ${ }^{6}$. Finally, depression appears to be highly persistent or recurrent in type 2 diabetes (or both) ${ }^{7}$, suggesting either that depression is overlooked and thus untreated in patients with diabetes or that depression is resistant to currently available treatment or both.

This raises the need to unravel the causes of the close relationship between diabetes and depression. Currently, however, the aetiology of depression in diabetes is poorly understood. One interpretation that received quite some attention is that psychological factors, such as the burden of life with a chronic disorder and particular events in the disease course of diabetes (development of complications and start of insulin treatment), predispose diabetes patients to depression. However, the bidirectional relationship between type 2 diabetes and depression suggests that shared biological mechanisms may also underlie the link between type 2 diabetes and depression. Such biological mechanisms are likely to parallel those events that increase the burden of disease in diabetes and thus their importance may be overlooked when focussing only on the burden-of-disease hypothesis. Yet only few studies have investigated such potential shared biological mechanisms. In this short commentary, we will discuss the role of three, partly entangled major pathophysiologic pathways, namely hyperglycaemia, (micro)vascular dysfunction, and inflammation, as potential mechanisms or common ground for the development of depression in type 2 diabetes.

\section{Hyperglycaemia and depression}

Hyperglycaemia itself may be a compelling regulator for mood states. Both fluctuations in plasma glucose as well as prolonged hyperglycaemia, as reflected in high HbA1c levels, may be involved in the development of depression in type 2 diabetes. The brain is particularly vulnerable to fluctuations in plasma glucose levels because neurons do not possess an active glucose transporter. As a result, high plasma glucose levels will have a direct effect on intraneuronal glucose levels. On a cellular level, these high intracellular glucose levels can activate the polyol pathway, thereby inducing oxidative stress and the enhanced formation of advanced glycation end products (AGEs), and both may lead to neuronal damage, which may eventually lead to depression ${ }^{8-10}$. In addition, increasing evidence suggests that hyperglycaemia leads to increased levels of cortisol $^{11}$, which is known to be involved in the development of depression.

Despite the plausibility of these mechanisms, it remains unclear whether there is a temporal association between blood glucose levels and the development of depression. A recent meta-analysis of longitudinal data on this topic ${ }^{12}$ showed no increased risk for depressive symptoms in individuals with prediabetes or newly developed diabetes, whereas there was an increased risk for individuals with clinically identified diabetes. However, the relatively small sample size and methods used to assess depression (that is, questionnaire but not a diagnostic interview) hinder a conclusive answer to the question of whether hyperglycaemia is causally related to depression. In addition, recent cross-sectional data have shown that AGEs, which form as a result of prolonged hyperglycaemia, are independently associated with major depressive disorder as assessed with a diagnostic interview; this argues in favour of a role for hyperglycaemia in the development of depression ${ }^{13}$. In order to address the question on the temporality of the association between hyperglycaemia and depression, there is a need for well-designed longitudinal population-based studies as well as mechanistic studies. These studies should assess continuous levels of hyperglycaemia parameters and determine depression on the basis of gold-standard assessment (that is, by interview) as opposed to questionnaires on depressive symptoms.

\section{Diabetes, depression, and (micro)vascular dysfunction} The vascular depression hypothesis proposes that vascular damage in frontal and subcortical regions of the brain, which are involved in mood regulation, may lead to depression in later life $^{14}$. In agreement with this hypothesis, recent longitudinal studies, as meta-analysed by van Agtmaal et al. ${ }^{15}$ and Rensma et $a l .{ }^{16}$, have indeed identified that various brain-scanning markers of cerebral small vessel disease (for example, white matter hyperintensities and lacunar infarctions) are associated with a higher risk of depressive symptoms. The vascular depression hypothesis may be especially relevant in type 2 diabetes because diabetes is strongly linked to cerebrovascular damage. Previous studies have reported that diabetes is associated with cortical infarctions ${ }^{17}$ and markers of more subtle vascular brain damage, including white matter hyperintensities ${ }^{18}$ and lacunes of presumed vascular origin ${ }^{19,20}$.

Further evidence linking diabetes and depression via vascular damage comes from aetiologic studies that investigated the pathways of microvascular dysfunction and arterial stiffening. These are considered crucial pathways early in the development of cerebrovascular damage ${ }^{21,22}$ and are known to be strongly related to diabetes as well ${ }^{23}$. The aforementioned meta-analysis by van Agtmaal et al. ${ }^{15}$ identified that various markers of microvascular dysfunction (for example, endothelial-derived blood biomarkers) were associated with depression ${ }^{15}$. These meta-analytic data showed small to moderate effect sizes and odds ratios ranging from 1.09 to 1.96 per standard deviation. Moreover, several cross-sectional studies have shown that arterial stiffness is higher in individuals with depression as 
compared with those without ${ }^{24-28}$. In addition, arterial stiffening has been associated with more depressive symptoms and this association was explained, or mediated, by brain-scanning markers of cerebral small vessel disease within the Ages Gene/Environment Susceptibility (AGES)-Reykjavik Study ${ }^{29}$. However, longitudinal evidence for an association between arterial stiffness and depression is missing.

Multiple studies thus show consistent neuroimaging and vascular correlates of both type 2 diabetes and depression separately. However, almost no studies have investigated the two disorders together. There is a paucity of both cross-sectional and longitudinal studies that have investigated both conditions and these pathophysiologic mechanisms in a sufficiently detailed manner. Such studies are needed to establish whether (micro) vascular damage indeed underlies the association between diabetes and depression.

\section{Low-grade inflammation, diabetes, and depression}

Low-grade inflammation is considered a key mediator of many chronic conditions. Type 2 diabetes is well known to be accompanied by systemic low-grade inflammation ${ }^{30}$, which is considered an important mechanism in the development of its cardiovascular complications ${ }^{31}$. Although the evidence is less extensive for depression, low-grade inflammation is indeed associated with incident depression ${ }^{32-34}$ and thus may represent a common biological pathway in the development of both type 2 diabetes and depression. Moreover, a recent meta-analysis shows that treatment resistance to antidepressants is associated with persistently elevated low-grade inflammation ${ }^{35}$. This may indicate that treatment-resistant depression has a different aetiology that is not captured by the most commonly used antidepressants (for example, selective serotonin reuptake inhibitors). Furthermore, previous trials suggest that anti-inflammatory therapy may be beneficial in depression ${ }^{36}$. The inflammatory pathway is likely to involve endothelial dysfunction and oxidative stress, and markers of these processes have been related to depression as well ${ }^{37,38}$. However, studies that specifically focus on this topic in relation to depression and type 2 diabetes are scarce ${ }^{39}$, and cross-sectional in nature, and therefore cannot support any conclusions about causality.

In summary, the available data may suggest that low-grade inflammation is a common ground of depression as well as cardiovascular disease in type 2 diabetes. However, there is a paucity of longitudinal data that can provide more robust evidence on this association. Despite this conclusion, the potential of low-grade inflammation as a prognostic tool for choosing the treatment modalities in individuals with both depression and type 2 diabetes may be large. Medication that targets low-grade inflammation may have beneficial effects on both depression and cardiovascular disease risk in type 2 diabetes.

\section{Future directions}

For all three pathophysiologic pathways discussed in this short commentary-hyperglycaemia, (micro)vascular dysfunction, and low-grade inflammation-greater understanding is needed on the temporal association between depression and type 2 diabetes. The vast majority of available studies have a cross-sectional design, thereby limiting the possibility of assessing the temporal sequence of the observed associations. Future studies should focus on a more detailed assessment of hyperglycaemia and depression in order to elucidate whether any causal association exists with depression. Although consistent associations on (micro)vascular dysfunction and low-grade inflammation with both type 2 diabetes and depression have been reported separately, almost no studies have investigated the two disorders together. Longitudinal studies across the life course are needed to assess the role of these potential shared mechanisms that link type 2 diabetes and depression. In addition, the biological mechanisms discussed in this commentary may well interfere with psychological mechanisms, as, for instance, is proposed in recent studies that link metabolism and psychopathology via the hypothalamic-pituitary axis, as suggested by the stress model ${ }^{40}$. Further study is needed to elucidate these interrelationships as well. The ultimate goal of improving our understanding of the underlying pathophysiology of depression and diabetes is to find new targets to successfully prevent and treat the co-occurrence of type 2 diabetes and depression.

\section{Abbreviations}

AGE, advanced glycation end product.

\section{Competing interests}

The authors declare that they have no competing interests.

\section{Grant information}

The author(s) declared that no grants were involved in supporting this work.
1. Ali S, Stone MA, Peters JL, et al.: The prevalence of co-morbid depression in adults with Type 2 diabetes: a systematic review and meta-analysis. Diabet Med. 2006; 23(11): 1165-73. PubMed Abstract | Publisher Full Text

2. Anderson RJ, Freedland KE, Clouse RE, et al.: The prevalence of comorbid depression in adults with diabetes: a meta-analysis. Diabetes Care. 2001; 24(6): 1069-78.

PubMed Abstract | Publisher Full Text F Rotella F, Mannucci E: Depression as a risk factor for diabetes: a metaanalysis of longitudinal studies. J Clin Psychiatry. 2013; 74(1): 31-7. PublMed Abstract | Publisher Full Text | F1000 Recommendation

4. Hutter N, Schnurr A, Baumeister $\mathrm{H}$ : Healthcare costs in patients with diabetes mellitus and comorbid mental disorders--a systematic review. Diabetologia. 2010; 53(12): 2470-9.

PubMed Abstract | Publisher Full Text 
5. F Molosankwe I, Patel A, José Gagliardino J, et al.: Economic aspects of the Fsociation between diabetes and depression: a systematic review. J Affect Disord. 2012; 142 Suppl: S42-55.

PubMed Abstract | Publisher Full Text | F1000 Recommendation

6. van Dooren FE, Nefs G, Schram MT, et al.: Depression and risk of mortality in people with diabetes mellitus: a systematic review and meta-analysis. PLoS One. 2013; 8(3): e57058.

PubMed Abstract | Publisher Full Text | Free Full Text

7. Nefs G, Pouwer F, Denollet J, et al.: The course of depressive symptoms in primary care patients with type 2 diabetes: results from the Diabetes, Depression, Type D Personality Zuidoost-Brabant (DiaDDZoB) Study. Diabetologia. 2012; 55(3): 608-16.

PubMed Abstract | Publisher Full Text | Free Full Text

8. Chen G, Xu R, Wang Y, et al:: Genetic disruption of soluble epoxide hydrolase is protective against streptozotocin-induced diabetic nephropathy. $\mathrm{Am} \mathrm{J}$ Physiol Endocrinol Metab. 2012; 303(5): E563-75. PubMed Abstract | Publisher Full Text | Free Full Text

9. Uribarri J, Woodruff S, Goodman S, et al:: Advanced glycation end products in foods and a practical guide to their reduction in the diet. J Am Diet Assoc. 2010; 110(6): 911-16.e12.

PubMed Abstract | Publisher Full Text | Free Full Text

10. Sima AA, Kamiya H, Li ZG: Insulin, C-peptide, hyperglycemia, and central nervous system complications in diabetes. Eur J Pharmacol. 2004; 490(1-3): 187-97.

PubMed Abstract | Publisher Full Text

11. F Moulton CD, Pickup JC, Ismail K: The link between depression and diabetes: the search for shared mechanisms. Lancet Diabetes Endocrinol. 2015; 3(6): $461-71$.

PubMed Abstract | Publisher Full Text | F1000 Recommendation

12. F Tong A, Wang X, Li F, et al.: Risk of depressive symptoms associated with impaired glucose metabolism, newly diagnosed diabetes, and previously diagnosed diabetes: a meta-analysis of prospective cohort studies. Acta Diabetol. 2016; 53(4): 589-98.

PubMed Abstract | Publisher Full Text | F1000 Recommendation

13. van Dooren FE, Pouwer F, Schalkwijk CG, et al.: Advanced Glycation End Product (AGE) Accumulation in the Skin is Associated with Depression: The Maastricht Study. Depress Anxiety. 2017; 34(1): 59-67.

PubMed Abstract | Publisher Full Tex

14. Taylor WD, Aizenstein HJ, Alexopoulos GS: The vascular depression hypothesis: mechanisms linking vascular disease with depression. Mol Psychiatry. 2013 18(9): 963-74.

PubMed Abstract | Publisher Full Text | Free Full Text

15. van Agtmaal MJM, Houben AJHM, Pouwer F, et al: Association of Microvascula Dysfunction With Late-Life Depression: A Systematic Review and Metaanalysis. JAMA Psychiatry. 2017; 74(7): 729-39. PubMed Abstract | Publisher Full Text | Free Full Text

16. Rensma SP van Sloten TT, Launer LJ, et al: Cerebral small vessel disease and risk of incident stroke, dementia and depression, and all-cause mortality: A systematic review and meta-analysis. Neurosci Biobehav Rev. 2018; 90: 164-73. systematic review and meta-analysis.
PubMed Abstract | Publisher Full Text

17. F Luitse MJ, Biessels GJ, Rutten GE, et al:: Diabetes, hyperglycaemia, and acute ischaemic stroke. Lancet Neurol. 2012; 11(3): 261-71. PubMed Abstract | Publisher Full Text | F1000 Recommendation

18. F Qiu C, Sigurdsson S, Zhang Q, et al.: Diabetes, markers of brain pathology and cognitive function: the Age, Gene/Environment Susceptibility-Reykjavik Study. Ann Neurol. 2014; 75(1): 138-46. PubMed Abstract | Publisher Full Text | Free Full Text | F1000 Recommendation

19. van Harten $\mathrm{B}$, de Leeuw $\mathrm{FE}$, Weinstein $\mathrm{HC}$, et al: Brain imaging in patients with diabetes: a systematic review. Diabetes Care. 2006; 29(11): 2539-48. PubMed Abstract | Publisher Full Text

20. F Moulton CD, Costafreda SG, Horton P, et al.: Meta-analyses of structural regional cerebral effects in type 1 and type 2 diabetes. Brain Imaging Behav. 2015; 9(4): 651-62.

PubMed Abstract | Publisher Full Text | F1000 Recommendation

21. Wardlaw JM, Smith EE, Biessels GJ, et al:: Neuroimaging standards for research into small vessel disease and its contribution to ageing and neurodegeneration. Lancet Neurol. 2013; 12(8): 822-38. PubMed Abstract | Publisher Full Text | Free Full Text

22. Mitchell GF, van Buchem MA, Sigurdsson S, et al:: Arterial stiffness, pressure and flow pulsatility and brain structure and function: the Age, Gene/
Environment Susceptibility--Reykjavik study. Brain. 2011; 134(Pt 11): 3398-407. PubMed Abstract | Publisher Full Text | Free Full Text

23. Muris DM, Houben AJ, Schram MT, et al:: Microvascular dysfunction is associated with a higher incidence of type 2 diabetes mellitus: a systematic review and meta-analysis. Arterioscler Thromb Vasc Biol. 2012; 32(12): 3082-94. PubMed Abstract | Publisher Full Text

24. Onete V, Henry RM, Sep SJS, et al:: Arterial stiffness is associated with depression in middle-aged men - the Maastricht Study. J Psychiatry Neurosci. 2017; 42(6): 160246

PubMed Abstract | Publisher Full Tex

25. Seldenrijk A, van Hout HP, van Marwijk HW, et al:: Depression, anxiety, and arterial stiffness. Biol Psychiatry. 2011; 69(8): 795-803. PubMed Abstract | Publisher Full Text

26. Tiemeier H, Breteler MM, van Popele NM, et al:: Late-life depression is associated with arterial stiffness: a population-based study. J Am Geriatr Soc. 2003; 51(8): 1105-10.

PubMed Abstract | Publisher Full Tex

27. Lewis TT, Sutton-Tyrrell K, Penninx BW, et al:: Race, psychosocial factors, and aortic pulse wave velocity: the Health, Aging, and Body Composition Study. J Gerontol A Biol Sci Med Sci. 2010; 65(10): 1079-85. PubMed Abstract | Publisher Full Text | Free Full Text

28. Paranthaman R, Greenstein AS, Burns AS, et al:: Vascular function in olde adults with depressive disorder. Biol Psychiatry 2010; 68(2): 133-9. PubMed Abstract | Publisher Full Text

29. van Sloten TT, Mitchell GF, Sigurdsson S, et al:: Associations between arterial stiffness, depressive symptoms and cerebral small vessel disease: crosssectional findings from the AGES-Reykjavik Study. J Psychiatry Neurosci. 2016; 41(3): 162-8.

PubMed Abstract | Publisher Full Text | Free Full Text

30. F Wang X, Bao W, Liu J, et al.: Inflammatory markers and risk of type 2 diabetes: a systematic review and meta-analysis. Diabetes Care. 2013; 36(1): $166-75$.

PubMed Abstract | Publisher Full Text | Free Full Text | F1000 Recommendation

31. Ross R: Atherosclerosis--an inflammatory disease. N Engl J Med. 1999; 340(2): $115-26$.

PubMed Abstract | Publisher Full Text

32. Howren MB, Lamkin DM, Suls J: Associations of depression with C-reactive protein, IL-1, and IL-6: a meta-analysis. Psychosom Med. 2009; 71(2): 171-86. PubMed Abstract | Publisher Full Text

33. Milaneschi Y, Corsi AM, Penninx BW, et al.: Interleukin-1 receptor antagonist and incident depressive symptoms over 6 years in older persons: the InCHIANTI study. Biol Psychiatry. 2009; 65(11): 973-8.

PubMed Abstract | Publisher Full Text | Free Full Text

34. Pasco JA, Nicholson GC, Williams LJ, et al:: Association of high-sensitivity C-reactive protein with de novo major depression. Br J Psychiatry. 2010; 197(5): $372-7$.

PubMed Abstract | Publisher Full Text

35. F Strawbridge R, Arnone D, Danese A, et al.: Inflammation and clinical response to treatment in depression: A meta-analysis. Eur Neuropsychopharmacol. 2015; 25(10): 1532-43. PubMed Abstract | Publisher Full Text | F1000 Recommendation

36. F Kappelmann N, Lewis G, Dantzer R, et al:: Antidepressant activity of anticytokine treatment: a systematic review and meta-analysis of clinical trials of chronic inflammatory conditions. Mol Psychiatry. 2018; 23(2): 335-43. PubMed Abstract | Publisher Full Text | Free Full Text | F1000 Recommendation

37. Hemingway $\mathrm{H}$, Shipley M, Mullen MJ, et al:: Social and psychosocial influences on inflammatory markers and vascular function in civil servants (the Whitehall II study). Am J Cardiol. 2003; 92(8): 984-7.

PubMed Abstract | Publisher Full Text

38. Lespérance $\mathrm{F}$, Frasure-Smith $\mathrm{N}$, Théroux $\mathrm{P}$, et al:: The association between major depression and levels of soluble intercellular adhesion molecule 1 , interleukin-6, and C-reactive protein in patients with recent acute coronary syndromes. Am J Psychiatry. 2004; 161(2): 271-7.

PubMed Abstract | Publisher Full Text

39. Laake JP, Stahl D, Amiel SA, et al:: The association between depressive symptoms and systemic inflammation in people with type 2 diabetes: findings from the South London Diabetes Study. Diabetes Care. 2014; 37(8): 2186-92. PubMed Abstract | Publisher Full Text

40. Petrak F: Depression and Diabetes. 2018. Reference Source 


\section{Open Peer Review}

\section{Current Peer Review Status:}

\section{Editorial Note on the Review Process}

Faculty Reviews are review articles written by the prestigious Members of Faculty Opinions. The articles are commissioned and peer reviewed before publication to ensure that the final, published version is comprehensive and accessible. The reviewers who approved the final version are listed with their names and affiliations.

\section{The reviewers who approved this article are:}

\section{Version 1}

\section{Jörg Huber}

School of Health Sciences, University of Brighton, Brighton, UK

Competing Interests: No competing interests were disclosed.

\section{Khalida Ismail}

Department of Psychological Medicine, Institute of Psychiatry, Psychology and Neuroscience, King's College London, London, UK

Competing Interests: No competing interests were disclosed.

The benefits of publishing with F1000Research:

- Your article is published within days, with no editorial bias

- You can publish traditional articles, null/negative results, case reports, data notes and more

- The peer review process is transparent and collaborative

- Your article is indexed in PubMed after passing peer review

- Dedicated customer support at every stage

For pre-submission enquiries, contact research@f1000.com 